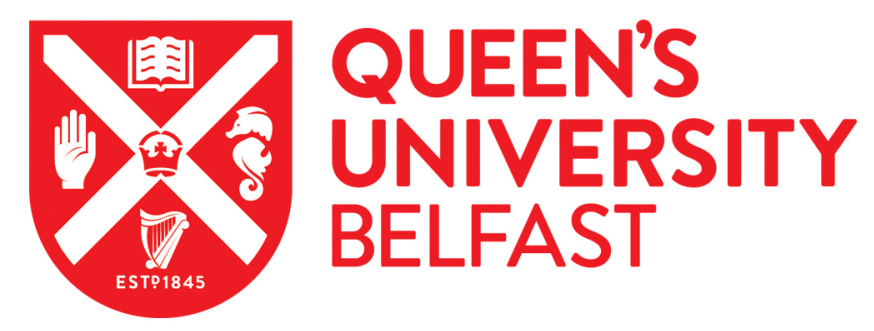

\title{
Predicting Takeover Targets: Long-run Evidence from the Netherlands
}

de Jong, A., \& Fliers, P. T. (2020). Predicting Takeover Targets: Long-run Evidence from the Netherlands. De Economist. https://doi.org/10.1007/s10645-020-09364-z

\section{Published in: \\ De Economist}

\section{Document Version:}

Peer reviewed version

Queen's University Belfast - Research Portal:

Link to publication record in Queen's University Belfast Research Portal

\section{Publisher rights}

(C) 2020 Springer Science+Business Media, LLC, part of Springer Nature. This work is made available online in accordance with the publisher's policies. Please refer to any applicable terms of use of the publisher.

\section{General rights}

Copyright for the publications made accessible via the Queen's University Belfast Research Portal is retained by the author(s) and / or other copyright owners and it is a condition of accessing these publications that users recognise and abide by the legal requirements associated with these rights.

Take down policy

The Research Portal is Queen's institutional repository that provides access to Queen's research output. Every effort has been made to ensure that content in the Research Portal does not infringe any person's rights, or applicable UK laws. If you discover content in the Research Portal that you believe breaches copyright or violates any law, please contact openaccess@qub.ac.uk. 


\title{
Predicting Takeover Targets: \\ Long-run Evidence from the Netherlands
}

\author{
ABE DE JONG* AND PHILIP FLIERS ${ }^{\#}$
}

March 2020

* Corresponding author. Monash University, Australia and Rotterdam School of Management, Erasmus University, The Netherlands, email: abe.dejong@monash.edu. \# Queen's University Belfast, Northern Ireland, email: p.fliers@qub.ac.uk.

The data for this project were collected as part of the NWO project 'The corporate governance of Dutch business in the 20th century - structural change and performance' (NWO 360-52080). We thank Chris Colvin, Marno Verbeek and an anonymous reviewer for providing comments and Mike Gruenwald, Teus Jan van Ekeren and Renate van der Meer for research assistance. 


\title{
Predicting Takeover Targets: Long-run Evidence from the Netherlands
}

\begin{abstract}
In the market for corporate control, the ownership and control of firms is traded. Mergers and acquisitions are major events for firms affecting the continuity and performance of firms and industries. This paper studies the determinants of takeovers in the Netherlands over a long period, 1961-2008. We conclude that until the mid-1980s targets had low leverage and high cash holdings. After this period, shareholder wealth maximization became a dominant goal, and we find that smaller and more profitable firms become targets for takeovers. In the most recent period takeover defences shield firms from takeover, while this effect is not found in the early period until the mid-1980s. We demonstrate shareholder rights have become important in determining takeover probabilities. The results illustrate the efficacy of rules and regulations and how they can affect the market for corporate control in the Netherlands.
\end{abstract}




\section{Introduction}

The key difference between private and publicly listed firms is that the latter group have shares trading at stock exchanges. This allows any investor to buy a significant portion of a firm's shares with which they can exert managerial control. While private firms are shielded from the market for corporate control, public firms are vulnerable to takeovers and acquisitions. Some argue that this market is a positive force, because it disciplines poorly performing firms to improve their performance and allows synergies to be generated in optimal business combinations (Manne, 1965). Others would refute this claim and argue that acquisitions in practice are often value-destroying because they are the outcome of - rather than a solution to - principal-agent problems (Jensen, 1986; Moeller, Schlingemann and Stulz, 2005). In order to describe the market for corporate control it is relevant to understand which firms are takeover targets, because this reveals the motives of acquiring firms in corporate takeovers. Additionally, it is important to understand how managers are able to frustrate the market for corporate control and how the instruments at their disposal (i.e. takeover defences) affect takeover probabilities.

In the wider corporate finance literature there is longstanding tradition of studies that predict takeover targets. The first study of this genre is probablySimkowitz and Monroe (1971), using multiple discriminant analysis to predict takeover targets. However, the seminal paper in the field is Palepu (1986) because heintroduced binomial logit modelling. More recent studies are Cremers, Nair and John (2009) and Shafer (2012), both of which investigate the US market for corporate control. Also outside the US empirical results are available, among others for Canada (Rege, 1984), the UK (Gaganis, Ouzounis and Zopounidis, 2009; Danbolt, Siganos and Tunyi, 2016), and multiple European countries (Brar, Giamouridis and Liodakis, 2009). However, we are unaware of a study of the Dutch market for corporate control.

The Netherlands offers an interesting setting to study takeovers and acquisitions because Dutch firms are internationally known for the anti-takeover measures that shield managers of from the market for corporate control (De Jong, Röell and Westerhuis, 2010). In an international comparison, the Dutch defence measures are unique because these legal barriers directly influence the opportunities for hostile acquirers (Adams and Ferreira, 2008), where in other countries structural barriers prevail, such as cross-holdings and pyramidal ownership. It is interesting to measure whether the Dutch legal takeover barriers are effective in deterring unwanted takeover attempts. 
This paper studies determinants of takeovers in the Netherlands over a long period of almost five decades, i.e. 1961-2008. In this period we find 200 successful takeovers. Although we also search for unsuccessful attempts, we find only fourteen in our sample, which is insufficient for testing the correlates of failed takeover attempts. We divide our long period in two subperiods, until 1985 and from 1986 onwards. The main reason for this division is that 1985 is a watershed in Dutch corporate governance, in this year the Amsterdam stock exchange started a discussion about takeover defences in their annual report, which induced a more negative perspective among stakeholder on these defences. Until the mid-1980, Dutch firms were typically owned by national institutional investors and large domestic shareholders. During this period, the Dutch economy operated as a coordinated market economy, where managers of large firms acted in the interest of all stakeholders. From the mid-1980 international influences - in particular from the US - brought shareholder wealth maximization as a competing perspective. The Dutch economy moved to a more liberal system (see Sluyterman, 2005; Westerhuis and De Jong, 2015).

We use discrete choice models predicting firm-year observations in which a successful takeover is found, using variables that capture general theories of takeovers, including inefficient management, a growth-resource mismatch, and undervaluation. In additional we control for takeover waves and include takeover defences and ownership information. All models are tested for the full period and for both subperiods. We find that the characteristics of takeover target differ between the two periods we distinguish. Until the mid-1980s targets had high cash holdings, which is an indication of inefficient management and growth-resource matching, because acquirers took over the cash-rich firm to better spend that cash. In the same period low leverage firms became targets. This is also indicative of inefficient management. This is becauselow leverage allows for additional use of the tax benefits of debt, but also that these firms lack the disciplining role of debt (Jensen, 1986). Interestingly, anti-takeover measures do not play any role in the process, which is consistent with a cooperative model, where managers of two firms would have to agree on friendly mergers in the interest of all stakeholders.

Shareholder wealth maximization became a dominant goal in the years after 1985. We find that the market for corporate control changed significantly. Most importantly, firms that are less protected by takeover defences are more likely to be targeted successfully. The flipside of this result - takeover defences deter takeovers - is an important result because of the heated debates 
on the relevance of takeover defences in the Dutch corporate landscape (Westerhuis and De Jong, 2015). The finding is also consistent with previous results that firms with takeover defences have lower market values (De Jong, DeJong, Mertens and Wasley, 2005) and with negative announcement returns when the preferred shares are deployed as a takeover defence (Kabir, Cantrijn and Jeunink, 1997). In addition we find in the second period evidence of growth-resource mismatching as smaller and more profitable firms become targets. Apparently, small and highly profitable firms with insufficient resources to growth organically can opt for a takeover by a larger and cash-rich firm to continue their growth.

Our analysis documents a significant shift in the logic of the Dutch market for corporate control in the wake of the shareholder revolution of the mid-1980s. Overall, we conclude the change from a coordinated market economy to a more liberal system, where shareholder value maximization became the first priority has significantly affected the market for corporate control. Not only did the determinants of successful takeover targets change, but so did the importance of the legal takeover defences, which are unique to the Dutch institutional setting.

In our view, the results of this study are relevant to Dutch researchers interested in mergers and acquisitions, but also in the longer term developments of the Dutch corporate governance system. In addition, Dutch policymakers can benefit from the insights of this study when regulating the market for takeovers and designing new governance codes. We demonstrate shareholder rights matter in takeovers, but also that the evolution towards shareholder primacy has influenced practices, and thus the efficiency of rules and regulation. Finally, we consider our study to be relevant for an international audience, because different institutional settings yield variations in takeover dynamics. Therefore, understanding a larger variety in capitalist settings adds to our understanding of takeover motives.

This paper is organized as follows. In Section 2 we discuss the relevant literature. Section 3 describes the Dutch institutional setting. In Section 4 we introduce the data and our empirical methods. Section 5 presents the results and robustness tests and Section 6 concludes.

\section{Literature review}

The takeover or acquisition of a publicly listed firm is a major event, both for the target and the acquirer. It has been widely documented that the target typically realizes a large positive 
return, while acquirers exhibit small, often negative, announcement returns (Moeller, Schlingemann and Stulz, 2005). This asymmetry stems from the premium the acquiring firm needs to pay to convince target shareholders to sell their shares. Because of this premium, it is attractive for investors to develop models to predict takeover targets. However, in addition to this investment or speculative perspective, models to distinguish target and non-target firms are informative about the motives for firms to engage in acquisitions and thus about the market for corporate control (Manne, 1965). In this section we describe motives for acquisition, from an acquirer and target viewpoint and we introduce methods for predicting targets and estimation of the determinants of acquisitions.

The first category of theories for acquisitions is inefficient management. In this perspective management teams are competing for the control over companies and an efficient outcome arises when the best management team gains control (Jensen and Ruback, 1983). Inefficiently run companies are taken over by an acquiring firm that replaces the management and removes inefficiencies. Characteristics of inefficient firms include are low performance (i.e. low profitability), and low market valuations relative to book values. In addition high cash reserves and low leverage are a sign of inefficient use of cash and suboptimal usage of the tax advantages of debt (Miller and Modigliani, 1963). Management can protect themselves against these disciplining takeovers by adopting anti-takeover devices and maintaining good relations with a large shareholders. Meanwhile, institutional investors may be more inclined to assist in a disciplining takeover. We focus on target firm characteristics because Jensen (1986) argues acquisitions can be an outcome of overinvestment; firms with weak governance acquire other firms to build corporate empires, because managers derive benefits from managing firms that are as large as possible.

A second group of motives are derived from growth-resource mismatch or synergy theories (Palepu, 1986; Damodaran, 2005). In this line of reasoning, after a merger the newly combined firm is worth more than the sum of its parts. Typically the merger involves a larger firm that is well-resourced in financial terms of cash,debt capacity, and in its ability to produce on a larger scale(i.e. utilize distribution networks) and a smaller, young firm with sufficient opportunities for growth but lacking the financial resources. As we focus on target characteristics, we expect these firms to be the profitable and highly valued firms, which are small in size and strapped of cash and debt capacity. Firms can improve the attractiveness for a takeover by depreciating 
their assets to lower values. Also, rival firms often take toeholds in attractive targets and we therefore expect industrial firm shareholdings to induce takeovers.

The third set of motives are labelled undervaluation. Due to the information differences between insiders and outsiders to the firm, the full value of the firm may not be reflected in its share values. In case the management cannot convince outside shareholders of the value of the firm, the share price will be low relative to the replacement value of the firm's assets (Palepu, 1986). In this case, it will be cheap to buy the shares relative to the asset value, to gain control. We expect this motive to prevail in smaller firms with intangible assets. Most importantly, undervaluation is measured directly as a low market-to-book value.

Another motivation why managers target and acquire other companies is market sentiment. That is, when equity markets are overvalued, managers are more likely to overestimate the potential synergies even though they can see that their own stock price is affected by the same overvaluation (Rhodes-Kropf and Viswanathan, 2004). While seemingly irrational, this behaviour can be fully explained by a rational model of (stock) mergers. In this setting, where managers of the bidding firm and the managers of the target firm have private information of their own firms, mispricing upon the closing of the deal has two components. First, a firm specific component (i.e. one for the bidder and one for the target), and, second, a market-wide component. Rhodes-Kropf and Viswanathan (2004) argue that in equilibrium stock bids reflect the expected level of synergies. However, as they argue, the target has limited information about the two components of the mis-valuation, and is unable to assess the potential synergies. More explicitly, the target managers, while knowledgeable of the fundamental value of their own company, are unable to infer whether the estimated synergies by the bidding company are a market effect, a sector effect, or a firm effect. In periods of high market valuations, merger activity can significantly increase if acquirors are able to pay higher prices, which is possible by issuing equity. This illustrates that in a hot market we expect takeover probabilities to be higher.

In Table 1 we present a summary of the four theoretical explanations of acquisitions and relate each theory to the firm characteristics discussed in the text.

\section{[Insert Table 1]}

The prediction of takeover targets has been an important area of the merger and acquisitions related research since the 1970s. The approach was derived from the one used in earlier 
research on predicting bankruptcies. (see Altman, 1968, for further reference). The focus on the prediction of takeover targets was likely facilitated by the third merger wave that took place between 1965 and 1969. As pointed out by Jucunda (2014), the primary aim of 1970s studies was to find common financial characteristics shared among companies that became an object of a takeover.

Simkowitz and Monroe (1971) are the first researchers we are aware of who attempt to distinguish between acquired and non-acquired firms based on financial characteristics. Like Altman (1968) in bankruptcy prediction, they use discriminant analysis, a method that is heavily dependent on the normality assumption of predictor variables. Substantial criticism of the 1970s studies was provided by Palepu (1986), who highlights that these studies suffered from several methodological flaws that led to biases in the estimationof failure probabilities and the estimation of the probabilities of firms being a target. Since 1980s, logistic regressions have become the dominant method used to predict takeover targets. The main reason is that logistic regression has much more relaxed assumptions, while the results are easier to interpret and more robust when underlying assumptions are violated (Eisenbeis, 1975).

Many studies have focused on predicting takeover targets in recent years (e.g. Hasbrouck, 1985; Shleifer and Vishny, 2003; Rossi and Volpin, 2004; Powell and Yawson, 2005). Almost all studies focus on the UK (e.g. Powell, 1997; Barnes, 1998; Gaganis, Ouzounis and Zopounidis, 2009; Danbolt, Siganos and Tunyi, 2016) or the US (e.g. Ambrose and Megginson, 1992; Walter, 1994; Cudd and Duggal, 2000). We are aware of one study for that examines multiple European countries (Brar, Giamouridis and Liodakis, 2009). While alternative models, such as multiple discriminant analysis, Cox-regression and many others have been suggested, most studies follow Palepu's (1986) logit model paired with the appropriate independent variables.

\section{Concentration and corporate control in the Netherlands}

The Netherlands has a small open economy and a long tradition of business activity including involvement in merger and acquisition activity (Van Zanden, 1997; Sluyterman, 2005). Therefore, global merger waves are likely to affect Dutch companies. Martynova and Renneboog (2008) review the literature on merger waves and discuss five waves, where the first so-called Great Merger Wave took place in the 1890s in the US. In the twentieth century 
the US witnessed a second merger wave in the 1920s, which extended into several European countries. Bouwens and Dankers (2012, pp. 68-71) document that in the Netherlands many firms where involved in mergers. During this period, Dutch firms typically engaged in horizontal mergers for the purpose of improvingtheir competitive position. ${ }^{1}$ Already in this early merger wave Dutch firms were involved in international takeovers. The third global merger wave took off in the 1950s and peaked in the late 1960s (Martynova and Renneboog, 2008). Many Dutch firms were involved in merger activities towards the end of the global wave, and again horizontal mergers were the dominant strategy. Although some firms also undertook diversifying acquisitions (Bouwens and Dankers, 2012, pp. 174-175). For example, the sugar producer CSM diversified with acquisitions in packaging, seed trade, leisure and foods. Interestingly, towards the end of this wave in 1970 the Social-Economic Council (SER) established procedural rules for mergers, including information provisions for shareholders and employees.

In the 1960s and 1970s most Dutch firms were owned by large domestic shareholders, such as institutional investors and wealthy individuals or families. These shareholders coordinated with the firm managers and the supervisory board, as was common in the coordinated market economy system (Sluyterman, 2005; Westerhuis and De Jong, 2015). The Dutch corporate climate and law stimulated managers of large firms to act in the interest of all stakeholders. In practice, this provided the managers with a well-protected position against disciplinary takeovers. The firms often had priority shares, preference shares and certificates. The former puts specific decision-making power in the hands of a few individuals, often loyal to the management. Priority shares are typically in a foundation to preserve the continuity of the firm. Priority shares have the statutory right to hire and fire managers and supervisors, for example in case of poor performance (Voogd, 1989). Certificates are non-voting shares issued by a trust or foundation, where the actual shares including the voting power would be held by this intermediary (Voogd, 1989). In the early 1970s protective preference shares become popular, as these instruments protect against hostile takeovers. In case of a threat these shares are placed with a befriended foundation, diluting the stake of the hostile shareholders (Westerhuis and De Jong, 2015). These three types of anti-takeover measures allowed firms to be shielded from the market for corporate control, which was consistent with the coordinated market economy of the 1960s and 1970s. In this respect, it is striking that in 1979 the first hostile takeover took

\footnotetext{
${ }^{1}$ Horizontal mergers, are mergers or consolidations that occur between firms that operate within the same industry and have similar operational characteristics.
} 
place in the Netherlands, when Lantana Beheer took over the N.V. Tilburgse WaterleidingMaatschappij (Nieuwe Leidsche Courant, November 3, 1979). The company had tried to implement an anti-takeover measure, but the shareholder voted against the use of takeover defenses.

The fourth global merger wave started in the 1980s, and many deals involved diversifying acquisitions that led to conglomerate firms. In the Netherlands, firms followed the international trend and the period of high economic growth led to many cross-border horizontal mergers. Then the fifth wave already starts in the 1990s and seems to be a continuation of the fourth wave, only interrupted by the 1987 stock market crash. The 1990s witnessed many large firms merging (Martynova and Renneboog, 2008; Bouwens and Dankers, 2012, pp. 230-232). In this period, national supervision became influenced by rules set by the European Commission, which aimed to limit mergers with negative effects on competition that would disadvantage consumers and yield disproportional market power to newly combined firms. In this period, we find the first takeover fights in the Netherlands. While hostile takeovers had not taken place after Lantana acquired the Tilburgsche Waterleiding-Maatschappij, in the 1980s Elsevier tried to acquire Kluwer in 1986 and Ahrend targeted Buhrmann-Tetterode in 1989 (Westerhuis and De Jong, 2015, p. 182). Both attempts failed, because of the use of anti-takeover devices.

In conjunction with the fourth merger wave, the Dutch economy moved to a more liberal market, among others because of influences from the US and also the UK, which introduced shareholder wealth maximization as the new dominant paradigm (Sluyterman, 2005; Westerhuis and De Jong, 2015). The shareholder base also changed, as domestic institutional investors started to diversify globally, at expense of their domestic holdings. At the same time, foreign investors bought up Dutch shares. These investors typically increased their holdings in large multinational firms. Also, shareholder value was promoted because remuneration packages of top managers increasingly included bonus and option plans. As a result, the orientation of Dutch firms changed to enhance market value, with less attention to the value for other stakeholders. However, the takeover defences were not immediately abolished and many firms embraced shareholder value and remuneration packages, but did not want to give up all the voting rights to the shareholders (De Jong, DeJong, Mertens and Wasley, 2005). Over a long transition period from the mid-1980s until the global financial crisis in 2007/2008, the landscape changed and takeover defences were slowly abolished or altered to give shareholders more influence (Westerhuis and De Jong, 2015). 
To conclude, in the entire period under investigation in the Dutch setting, the market for corporate control can be frustrated by firm top management that is unwilling to sell to an acquirer, when the acquirer makes an offer motivated by inefficiencies, synergies or undervaluation. With the help of takeover defences or by colluding with a large shareholder, the management that is under attack of a hostile takeover, can successfully deter the acquisition attempt. In other words, with takeover defences and large shareholders, the three sets of motives may not be actually observable in our data. It should be noted that this applies particularly to inefficiency and undervaluation, where the management is most likely to resist a takeover, because they are likely to be replaced by a new management team. Of course, it is very interesting to test the effects of takeover defences on the probability of a takeover, because this measures the effectiveness of the legal barriers. In case the defences reduce takeover probabilities, they are an effective device and can shield managers from the market for corporate control. The absence of an effect would be evidence of managers making their decisions independent of the pressure of the market for corporate control.

Previous research on mergers and acquisitions in the Netherlands has focused on the shareholder wealth effects upon the announcements of mergers and acquisitions. Frederikslust, Van der Wal and Westdijk (2000) investigate the period 1954-1997 and find that the 101 mergers result in an $11.9 \%$ cumulative abnormal return for targets and $0.25 \%$ for acquirers. This implies that stock market participants expect synergies, but that the target companies manage to capture the entire premium, on average. Corhay and Tourani Rad (2000) study takeovers of foreign firms by Dutch companies in the 1990s and find weak evidence that the announcement lead to positive abnormal returns. Finally, De Jong, Van der Poel and Wolfswinkel (2007) measure announcement effects of 865 acquisition announcements in the years 1993-2004 and conclude that the average effect is a positive 1.1\% return for acquirers, but also find that the dispersion of outcomes is very large.

\section{Data and empirical method}

Our data comprises all Dutch companies listed on the Amsterdam Stock Exchange between 1961 and 2008 and mentioned in the Van Oss Effectenboek or the database of the Dutch institution for national statistics (Centraal Bureau van de Statistiek) on the one hand, and Gids bij de Officiële Prijscourant on the other hand. We require to have all data available for our 
variables. Our sample consists 574 unique firms, 3,224 observations, with 200 successful takeovers. As our aim is to predict takeovers throughout the period 1961-2008, we estimate various logistic regressions. Equation 1 highlights our specification.

$$
\log _{e} \frac{\pi_{i, t}(\text { Takeover })}{1-\pi_{i, t}(\text { Takeover })}=\beta_{1} X_{i, t}+\phi
$$

We define the left-hand-side variable, $\log _{e} \frac{\left.\pi_{i, t} \text { (Takeover }\right)}{\left.1-\pi_{i, t} \text { (Takeover }\right)}$, as the $\log$ odds ratio that firm's will be a takeover target. $X_{i, t}$ is a vector of explanatory variables. ${ }^{2}$ Additionally, our estimations include industry fixed effects $(\phi){ }^{3}$ Standard errors are clustered at the industry level. While we specify equation (1) in terms of log odds, our tables with regression estimates report the average marginal effects, for simplicity and the ease of interpreting the effect size. We report $z$-statistics in parentheses and use conventional levels for significance testing. We distinguish in our estimation observations until and after 1985, in order to capture the shift in the Dutch economy from a coordinated market system to a more liberal system and the potential changes in the effects of anti-takeover measures (Sluyterman, 2005; Westerhuis and De Jong, 2015).

Our variables of interest are the following: Firm size is the natural logarithm of the firm's total assets expressed in 2008 values and in guilders (the Dutch currency in the largest part of our period; in 2002 the guilder was replace by the euro at a rate of 2.20 guilders per euro). Tangibility is the ratio of the firms fixed assets to total assets. Depreciation is the total annual amount depreciated on the firm's assets, scaled by total assets. Profitability is defined as the firm's return on assets (i.e. earnings before interest over total assets). Market-to-book is the market value of the firm's equity to the book value of equity. Leverage is the firm's total debt scaled by total assets. Cash is cash and bank holdings scaled by total assets. M\&A market sentiment is equal to 1 if a year ranks in the fourth quartile of merger and acquisition activity between 1961 and 2008. We assume that in years with strong positive sentiments and accommodating conditions for mergers and acquisitions, firms are more likely to be taken over. Because we aim to provide an extensive description of takeover probabilities, we want to control for these sentiments. However, because the sentiments are unobservable, we use the

\footnotetext{
${ }^{2}$ All relevant and continuous variables are winsorized at the $5 \%$ level (i.e. $2.5 \%$ on either end of the distribution).

${ }^{3}$ In robustness tests we also include decade fixed effects to capture macroeconomic fluctuations not captured by our M\&A market sentiment variable. We find that all our results are robust.
} 
takeover activity from our sample, even though this a tautological definition. We expect the coefficient to by positive in all specification, in case takeovers are clustered in time.

The variable Number of takeover defences counts the number of total takeover defences in place for each firm at the end of the year, from a set of three defences. Based on Voogd (1989) we identify three prominent takeover defences (binary indicators); (1) the presences of antitakeover preference shares; (2) the trading of certificates and; (3) the presence of priority shares.

We distinguish five main industries and add indicator variables for light industrial firms, heavy industrial firms, retail firms, transportation firms, and service firms. For our robustness analysis we define three additional variables. Average two-year growth is the change in total assets over the past two years. Two-year compounded growth rate is the two-year compounded growth of total assets. Investments is the change in fixed assets corrected for depreciation.

For a subsample (from 1992) we also have ownership information, identifying blockholders and their identity. Blockholders is a binary variable equal to one if and only if a shareholder is present owning more than five percent of the firm's share (including institutional shareholders). Additionally we have information on the percentage of shares held the following investors: (1) financial institutions (not pension fund or insurance company); (2) pension funds; (3) insurance companies; (4) industrials and; (5) private individuals.

\section{Results}

Before discussing the main results of our analysis, we highlight some of the characteristics of our sample. Table 2, Panel A shows the descriptive statistics of our sample composition. Our sample consists of 574 unique firms over the period 1961-2008, which yields 3,424 firm-year observations. Of these 574 firms, 372 firms have never received a takeover bid during the period, while 202 did receive an offer. The annual unconditional takeover probability is approximately 6 percent (i.e. 214 takeover bids out of 3,424 observations). We find that takeover probabilities in our data set slightly increase after 1985. We have very few unsuccessful bids and in further analyses we omit these observations from the sample. That is, in our analysis, all takeover bids included represent M\&A announcements that result in an actual merger or acquisition. 


\section{[Insert Table 2]}

Table 2, Panel B shows the descriptive statistics for all variables employed in our analysis. We provide descriptive statistics for the full period, as well as for the periods 1961-1985 and 19862008. We find that firms in our sample become larger, less profitable, and become more highly valued (relative to their book value) by investors after 1985. Moreover, firms employed more takeover defences after 1985. This finding is slightly counter-intuitive, because the shareholder revolution of the mid-1980s did make takeover defences less popular among investors. However, managers also have an incentive to protect themselves against more opportunistic and active shareholders and employed more takeover defences. Additionally we find that priority shares were used less after 1985, however preference and certificates are used more. Preference shares are only introduced in the early 1970s. Table 3 shows the comparison of target and non-target firms in the two periods we distinguish.

\section{[Insert Table 3]}

In the period from 1961 to 1985 we find that targets were predominantly firms with relatively low levels of fixed assets and low leverage. Additionally, target firms held approximately 1.3 times more cash than non-targets. With respect to takeover defences, target firms used significantly less priority shares. For the period 1986-2008, target firms depreciated their assets more and were relatively small. We find that target firms used fewer takeover defences, primarily the used less priority shares than non-target firms. Overall, we find that the univariate statistics reveal that the determinants of firms' likelihoods to be takeover candidates have significantly changed after the mid-1980s. More generally, in the first period 83 percent of the targets are acquired during an M\&A market with positive sentiment, whereas for the second period only 52 percent of all acquisitions occur under these market conditions. We will provide more interpretation to these findings when examining multivariate logit models.

In Table 4 we present a series of logit models to predict whether a firm receives a takeover bid or not for the full period. Our staggered setup allows us to examine the different categories of variables important for corporate takeovers. We specify two baseline models and explain our results.

\section{[Insert Table 4]}


Table 4 column (7) shows our baseline results including the number of takeover defences. We find that firms that depreciate more, are less profitable, have more cash holdings and operate in a period with positive $M \& A$ sentiment, are more likely to be acquired. Firms that depreciate more, ready their balance sheet to reflect the true value of their assets, making them a more attractive takeover target. The result that less profitable firms are more likely to be targeted is consistent with an efficient market for corporate control, where poorly performing firms are taken over and restructured. Firms with more cash holdings have more financial flexibility and can provide coinsurance to potential acquirers (e.g. Shastri, 1990; Billet, King and Mauer, 2004). Acquirers can take over a cash-rich firm can pay down their risky debt. Moreover, in times when merger and acquisition activity is high, takeover probabilities are 3.4 percent higher. Additionally, we find that profitable firms are less likely to be acquired. Highly profitable firms are valued highly and are thus more expensive to acquire.

Consistent with the Dutch institutional arrangements, we find that firms with more takeover defences have significantly lower takeover probabilities. This implies that the legal barriers are effective in deterring takeovers. From the reported average marginal effects, we find that for each additional takeover defence in place, takeover probabilities decrease by approximately 90 basis points (bps). Column (8) subsequently, shows the same results, however we make a distinction between different takeover defences firms employed. We find that the negative effect of takeover defences is primarily driven by the existence of priority shares outstanding $(-140 \mathrm{bps})$.

To provide a deeper understanding of how corporate takeover probabilities changed as the Dutch economy transformed into a more liberal market economy during the mid-1980s, we split our sample period in the year until 1985 and from 1986 onwards, and we investigate the impact of this structural change. Table 5 shows the result of this analysis. Additionally, we report Shapely variance decomposition statistics, which allows us to assess the importance of each of the determinants in explaining the variance in takeover probabilities. ${ }^{4}$ Also, we report for each of our estimations the model's ROC characteristics, assessing the predictive ability of our models (e.g. Taylor, 2012; Colvin, De Jong and Fliers, 2015). Column (1) repeats our baseline model from Table 4. Column (2) then shows the inclusion of a simple binary indicator,

\footnotetext{
${ }^{4}$ While perhaps uncommon in economics, we report the decomposition of the explained variance of each of our estimations (e.g. Colvin, De Jong and Fliers, 2015). This procedure allows us to to explore how much power each category of variables have in explaining corporate failures. Combined with our sub-period analysis, this allows us to demonstrate the variability of takeover determinants.
} 
which is equal to one after 1985 . We find that takeover probabilities are 10 percent lower after 1985. In the remainder of our analysis we aim to explain these differences before and after 1985. Columns (3) and (4) shows the estimation results when we estimate the model separately for each of the two sub-periods.

\section{[Insert Table 5]}

The effects in the two periods are statistically and economically significant for several variables and, most importantly, differ between these periods. During the early period 1961-1985, firms high on cash would be much more likely takeover candidates. That is, we find that if the average firm doubles the cash position, the probability of becoming a takeover target would increase by 34 basis points. ${ }^{5}$ Similarly, firms with higher leverage were significantly less likely to be a target. We find that in case the average firm increases its leverage by one standard deviation its takeover probability would decrease by approximately 38 basis points. Most strikingly, takeover defences have no effect, after correcting for other factors. This finding is enforced by the relatively low Shapely value for takeover defences. ${ }^{6}$ In other words, the takeover defences are hardly relevant determinants of a takeover. Apparently, during the early period, strategic collaborations were negotiated behind closed doors without relevance of shareholder rights or pressure.

In the later period 1986-2008, we find significantly different results. For example, we find that the coefficients on firm size, tangibility, profitability, cash, hot market and takeover defences are significantly different from the previous period. ${ }^{7}$ We find that smaller firms, firms with more collateral, higher profitability and less cash reserves are more likely to become takeover targets, compared to the previous period.

More important is that we find that in the recent period firms can successfully deter takeovers by having more defences, explaining as much as 29 percent of the variation. So, the acquisitions that do take place allow the predators to grow profitably, while firms - that want to stay independent or shield from disciplining - can successfully frustrate the market for corporate control. Columns (5) and (6) of Table 5 separate the effect of takeover defences. We find that

\footnotetext{
${ }^{5}$ The economic effects canbe interpreted as follows. The average firm in our sample as a cash position of $4.67 \%$ (of total assets), doubling this cash position (keeping everything else equal), would increase the cash position by $4.67 \%$. A one unit increase in would increase takeover probabilities by 730 basis points. Consequently a $4.67 \%$ increase results in a 34 basis point increase in takeover probabilities.

${ }^{6}$ The intuition here is, that takeover defenses only add little value in contributing to the overall explanatory power of our model in the first period.

${ }^{7}$ We compare coefficients between the different models using a Wald test.
} 
after 1985 indeed takeover defences become more important and are effective across the board in deterring takeovers. Preference shares reduce takeover probabilities by approximately 3 percent, outstanding certificates reduce the chances of a takeover by 2.4 percent and priority shares reduce probabilities by approximately 4 percent. Moreover, we find that this division in type of takeover defences is in fact important, without the separation the Shapely explanatory power is only 29 percent, compared to 34 percent when including the different types.

\section{[Insert Table 6]}

While takeover defences might have become more important after 1985, this effect might very well be driven by changes in corporate ownership structure. To this end, we collect information on blockholders (i.e. shareholders, holding more than 5 percent of the shares of a firm). In Table 6 we consider the most recent period and add these ownership variables, which data is only available after 1992. We discuss our results for the period 1992-2008.

We find that when we include ownership and blockholder information into our analysis, all our previous results hold. Column (2) shows that ownership (i.e. the presence of a blockholder) does not matter for takeover probabilities. In the subsequent columns, we include information on the percentage of shares held by different blockholders and whether these blockholders maintain a controlling interest in the firm ( $>50 \%$ of the shares). ${ }^{8} \mathrm{We}$ find that the presence of financial institutions increases the probability of takeovers as they are primarily interested in capturing returns upon announcement of takeovers. We also find that industrials (i.e. nonfinancial corporations) increase the takeover probabilities. This finding illustrates the importance of so called toe-holds, as their stake (over 5 percent) is most likely to acquire the company in the future. Ultimately we find that blockholders and takeover defences account for approximately $45 \%$ of the explained variance in takeover probabilities. We conclude that takeover defences indeed lower the probability of a successful takeover and that the presence of different shareholders is important in this context.

We conclude with a set of robustness tests, reported in Table 7.

\section{[Insert Table 7]}

\footnotetext{
${ }^{8}$ We test additional cut-off points for the presence of a blockholder and find no different effects. As such, we focus on the presence of a blockholder with controlling interest. We thank an anonymous referee for this suggestion.
} 
In column (1) we include decade fixed effects, column (2) includes a variable to capture corporate asset growth, column (4) includes investments (i.e. changes in fixed assets in place) and column (5) includes only those firms with a minimum of four observations per firm. We find in Table 7 that all our primary results hold.

\section{Conclusion}

This paper investigates the determinants of takeover probabilities in the Dutch economy. We document a significant shift in the logic of the Dutch market for corporate control in the wake of the shareholder revolution of the mid-1980s. Overall, we conclude that the change from a coordinated and cooperative market economy to a more liberal system where shareholder value maximization became the first priority significantly affected the market for corporate control. Not only did the determinants of successful takeover targets change, but so did the importance of legal takeover defences.

Prior to the mid-1980s, takeover targets were characterized as flushed with cash and operating with low leverage. That is, the focus of acquirors was primarily on target companies that were inefficiently managed or fit with the acquiror's growth and resource strategies. We find that in this era takeover defences were not relevant, probably because in this cooperative system, the main stakeholders would maintain good relations with each other, without seeking disciplinary measures, such as hostile takeovers. It is interesting that acquisitions may have served to improve efficiency, without the pressure from the market for corporate control. Obviously, this is a conjecture, because further research would have to prove that the actual efficiency after the acquisition has improved.

In the wake of the shareholder revolution, driven by developments in the US and UK, the Dutch market for corporate control changed significantly. More explicitly, after 1985 takeover probabilities increased by approximately ten percent. Moreover, after 1985 the determinants of takeover probabilities have changed. We find that in this period small and profitable companies were primarily the focus of acquirors. We conclude, that during this period firms with insufficient resources to growth could opt for a takeover by a larger and cash-rich firm to continue growth.Firms were also able to frustrate the market for corporate control by using takeover defences. Takeover defences became approximately 5 times more important in determining takeover probabilities as the Dutch economy moved from a stakeholder based 
approach to a system where shareholder value maximization was the main objective. Our analysis is robust to the inclusion of ownership structure of Dutch corporations, this analysis harbours some interesting conclusions. We find that the presence of blockholders did not determine the takeover probabilities, it was the identity or the type of blockholders that matter. We conclude that after 1985, managers were able to frustrate the market for corporate control by employing takeover defences or finding institutional shareholders (pension funds) at their side.

Overall, this paper is the first to study the Dutch takeover market. By employing a unique data set we are able to analyse the determinants of takeover probability, their relevance in two distinct periods and draw conclusions on the determinants of successful Dutch takeovers. More importantly, this paper sheds light on the efficacy of takeover defences. We shed a light on the heated debates on the relevance of takeover defences in the Dutch corporate landscape. Takeover defences are relevant, economically important and indeed successful in deterring unwanted or unsolicited takeover bids. 


\section{References}

Adams, R. and Ferreira, D. (2008). One share-one vote: The empirical evidence. Review of Finance, 12(1), 51-91.

Altman, E. I. (1968). Financial ratios, discriminant analysis and the prediction of corporate bankruptcy. The Journal of Finance, 23(4), 589-609.

Ambrose, B.W. and Megginson, W.L. (1992). The role of asset structure, ownership structure, and takeover defences in determining acquisition likelihood. Journal of Financial and Quantitative Analysis, 27 (4), 575- 589.

Barnes, P. (1998), Can takeover targets be identified by statistical techniques?: Some UK evidence. Journal of the Royal Statistical Society: Series D (The Statistician), 47: 573591.

Billett, M. T., King, T. H. D. and Mauer, D. C. (2004). Bondholder wealth effects in mergers and acquisitions: New evidence from the 1980s and 1990s. The Journal of Finance, 59(1), 107-135.

Bouwens, B. and Dankers, J. (2012). Tussen concurrentie en concentratie. Belangenorganisaties, kartels, fusies en overnames. Amsterdam: Boom.

Brar, G., Giamouridis, D. and Liodakis, M. (2009) Predicting European takeover targets. European Financial Management, 15 (2), 430-450.

Coase, R. H. (1937). The nature of the firm. Economica, 4(16), 386-405.

Colvin, C., De Jong, A. and Fliers, P.T. (2015). Predicting the past: Understanding the causes of bank distress in the Netherlands in the 1920s. Explorations in Economic History, 55, 97-121.

Corhay, A. and Tourani Rad, A. (2000). International acquisitions and shareholder wealth. Evidence from the Netherlands. International Review of Financial Analysis, 9(2), 163174.

Cremers, K.M., Nair, V.B. and John, K. (2009) Takeovers and the cross-section of returns. Review of Financial Studies, 22 (4), 1409-1445.

Cudd, M., and Duggal, R. (2000). Industry distributional characteristics of financial ratios: an acquisition theory application. Financial Review, 35(1), 105-120.

Damodaran, A. (2005). The value of synergy. Stern school of Business, 132-146.

Danbolt, J., Siganos, A. and Tunyi, A. (2016), Abnormal returns from takeover prediction modelling: Challenges and suggested investment strategies. Journal of Business Finance \& Accounting, 43: 66-97. 
De Jong, A., DeJong, D., Mertens, G. and Wasley, C. (2005). The role of self-regulation in corporate governance. Journal of Corporate Finance, 11, 473-503.

De Jong, A., Van der Poel, M. and Wolfswinkel, M. (2007). Corporate governance and acquisitions: Acquirer wealth effects in the Netherlands, in: Corporate governance and regulatory impact on mergers and acquisitions: research and analysis on activity worldwide since 1990, G. Gregoriou and L. Renneboog (Eds.), Elsevier, 131-161.

De Jong, A., Röell, A. and Westerhuis, G. (2010). Changing national business systems: Corporate governance and financing in the Netherlands, 1945-2005. Business History Review, 84 (4), 773-798.

Gaganis, C., Ouzounis, G. and Zopounidis, C. (2009). Prediction of acquisitions and portfolio returns. International Journal of Banking, Accounting and Finance, 1 (4), 381-406.

Hasbrouck, J. (1985). The characteristics of takeover targets Q and other measures. Journal of Banking and Finance, 9 (3), 351-362.

Jensen, M. C. (1986). Agency costs of free cash flow, corporate finance, and takeovers. The American Economic Review, 76 (2), 323-329.

Jensen, M. C., and Ruback, R. S. (1983). The market for corporate control: The scientific evidence. Journal of Financial Economics, 11(1-4), 5-50.

Jucunda, M. E. (2014). Characterizing and predicting takeover targets: a review. Research Journal of Management Sciences, 3(2), 19-23.

Kabir, M.R., Cantrijn, D. and Jeunink, A. (1997). Takeover defences, ownership structure and stock return in the Netherlands: An empirical analysis. Strategic Management Journal, $18(2), 97-109$.

Manne, H. G. (1965). Mergers and the market for corporate control. Journal of Political Economy, 73(2), 110-120.

Martynova, M. and Renneboog, L. (2008). A century of corporate takeovers: What have we learned and where do we stand? Journal of Banking and Finance, 32 (10), 2148-2177.

Modigliani, F. and Miller, M.H. (1963). Corporate income taxes and the cost of capital: A correction. The American Economic Review, 53 (3), 433-443.

Moeller, S. B., Schlingemann, F. P., and Stulz, R. M. (2005). Wealth destruction on a massive scale? A study of acquiring-firm returns in the recent merger wave. The Journal of Finance, 60(2), 757-782.

Palepu, K. G. (1986). Predicting takeover targets: A methodological and empirical analysis. Journal of Accounting and Economics, 8(1), 3-35. 
Powell, R.G. (1997). Modelling takeover likelihood, Journal of Business Finance \& Accounting, 24 (8), 1009-1030.

Powell, R.G., and Yawson, A. (2005). Industry aspects of takeovers and divestitures: Evidence from the UK. Journal of Banking \& Finance, 29(12), 3015-3040.

Rege, U.P. (1984). Accounting ratios to locate take-over targets. Journal of Business Finance \& Accounting, 11(3), 301-311.

Rhodes-Kropf, M., and Viswanathan, S. (2004). Market valuation and merger waves. The Journal of Finance, 59(6), 2685-2718.

Rossi, S., and Volpin, P. F. (2004). Cross-country determinants of mergers and acquisitions. Journal of Financial Economics, 74(2), 277-304.

Shastri, K, 1990, The differential effects of mergers on corporate security values, Research in Finance 8, 179-201.

Shleifer, A. and Vishny, R. W. (2003). Stock market driven acquisitions. Journal of financial Economics, 70(3), 295-311.

Simkowitz, M. and Monroe, R.J. (1971). A discriminant analysis function for conglomerate targets. Southern Journal of Business, 6 (1), 1-15.

Sluyterman, K.E. (2005). Dutch enterprise in the 20th century: Business strategies in a small open country. Abingdon: Routledge.

Taylor, A.M. (2012). The great leveraging. NBER Working Paper. No. 18290.

Van Frederikslust, R.A.I., Van der Wal, V. and Westdijk, H. (2000). Effecten van fusies and acquisities op aandelenrendementen: Theorie en Empirie. Maandblad voor Accountancy and Bedrijfseconomie, June, 264-282.

Voogd, R. P. (1989). Statutaire beschermingsmiddelen bij beursvennootschappen (Doctoral dissertation: Nijmegen.

Walter, R. M. (1994). The usefulness of current cost information for identifying takeover targets and earning above-average stock returns. Journal of Accounting, Auditing \& Finance, 9(2), 349-377.

Westerhuis. G. and De Jong, A. (2015). Over geld en macht. Financiering en corporate governance van het Nederlandse bedrijfsleven, Amsterdam: Boom.

Zanden, van J.L. (1997). Een klein land in de 20e eeuw, Utrecht: Het Spectrum. 
Table 1: Theories and firm characteristics

\begin{tabular}{|c|c|c|c|c|}
\hline & $\begin{array}{r}\text { Inefficient } \\
\text { management }\end{array}$ & \begin{tabular}{l}
\multicolumn{1}{c}{ Resource } \\
mismatch \\
and synergies
\end{tabular} & $\begin{array}{c}\text { Under- } \\
\text { valuation }\end{array}$ & Sentiment \\
\hline Firm size & & Negative & Negative & \\
\hline Tangibility & & & Positive & \\
\hline Depreciation & & Positive & & \\
\hline Profitability & Negative & Positive & & \\
\hline Market value & Negative & Positive & Negative & \\
\hline Leverage & Negative & Positive & & \\
\hline Cash & Positive & Negative & & \\
\hline Hot market & & & & Positive \\
\hline Takeover defenses & Negative & & & \\
\hline Blockholders & Negative & & & \\
\hline Financial shareholders & Positive & & & \\
\hline Industrial shareholders & & Positive & & \\
\hline
\end{tabular}


Table 2: Descriptive statistics

\section{Panel A: Takeover descriptive statistics}

\begin{tabular}{|c|c|c|c|c|c|c|c|}
\hline \multirow[b]{2}{*}{ Categorie } & \multirow[b]{2}{*}{ Definition } & \multicolumn{2}{|c|}{ Full sample } & \multicolumn{2}{|c|}{ 1961-1985 } & \multicolumn{2}{|c|}{ 1986-2015 } \\
\hline & & Firm-Year & Unique firms & Firm-Year & Unique firms & Firm-Year & Unique firms \\
\hline All firms & All firms included in the sample & 3,424 & 574 & 2,084 & 357 & 1,340 & 217 \\
\hline Non-targets & Firms that never receive a takeover bid & 3,210 & 372 & 1,963 & 243 & 1,247 & 129 \\
\hline Targets & Firms that receive a takeover bid in the next year & 214 & 202 & 121 & 114 & 93 & 88 \\
\hline Unsuccessful & Firms that receive an unsuccessful takeover bid & 14 & 12 & 8 & 7 & 6 & 5 \\
\hline
\end{tabular}

Note: The number of firm-year observations include each year with sufficient data for all firms in our sample. 
Table 2: Descriptive statistics (cont.)

Panel B: Sample descriptive statistics with subperiods

\begin{tabular}{|c|c|c|c|c|c|c|c|}
\hline \multirow[b]{2}{*}{ Variables } & \multicolumn{2}{|c|}{ Full sample } & \multicolumn{2}{|c|}{$1961-1985$} & \multicolumn{2}{|c|}{$1986-2008$} & \multirow{2}{*}{$\begin{array}{r}\text { Difference } \\
\text { T-test } \\
\text { statistic }\end{array}$} \\
\hline & $\mathrm{N}$ & mean & $\mathrm{N}$ & mean & $\mathrm{N}$ & mean & \\
\hline Successful takeover bid & 3,424 & 0.058 & 2,084 & 0.054 & 1,340 & 0.065 & 1.28 \\
\hline Firm size (mln, 2008 guilders) & 3,424 & 1,319 & 2,084 & 378 & 1,340 & 2,782 & $13.772 * * *$ \\
\hline Tangibility & 3,424 & 0.319 & 2,084 & 0.320 & 1,340 & 0.316 & -0.617 \\
\hline Depreciation & 3,424 & 0.043 & 2,084 & 0.041 & 1,340 & 0.048 & $6.183 * * *$ \\
\hline Profitability & 3,424 & 0.097 & 2,084 & 0.110 & 1,340 & 0.078 & $-9.759 * * *$ \\
\hline Market-to-book & 3,424 & 2.150 & 2,084 & 1.941 & 1,340 & 2.475 & $7.609 * * *$ \\
\hline Leverage & 3,424 & 0.485 & 2,084 & 0.461 & 1,340 & 0.523 & $10.14 * * *$ \\
\hline Cash & 3,424 & 0.047 & 2,084 & 0.023 & 1,340 & 0.084 & $20.318 * * *$ \\
\hline Hot M\&A Market & 3,424 & 0.389 & 2,084 & 0.454 & 1,340 & 0.287 & $-10.104 * * *$ \\
\hline Number of takeover defenses & 3,424 & 1.078 & 2,084 & 0.838 & 1,340 & 1.452 & $21.842 * * *$ \\
\hline Preference shares & 3,424 & 0.386 & 2,084 & 0.193 & 1,340 & 0.687 & $32.235 * * *$ \\
\hline Certificates & 3,424 & 0.279 & 2,084 & 0.218 & 1,340 & 0.373 & $9.664 * * *$ \\
\hline Priority shares & 3,424 & 0.413 & 2,084 & 0.427 & 1,340 & 0.392 & $-2.024 * *$ \\
\hline Light industrials & 3,424 & 0.216 & 2,084 & 0.276 & 1,340 & 0.122 & $-11.638 * * *$ \\
\hline Heavy industrials & 3,424 & 0.393 & 2,084 & 0.391 & 1,340 & 0.397 & 0.375 \\
\hline Retail & 3,424 & 0.124 & 2,084 & 0.146 & 1,340 & 0.091 & $-4.972 * * *$ \\
\hline Transportation & 3,424 & 0.070 & 2,084 & 0.086 & 1,340 & 0.046 & $-4.82 * * *$ \\
\hline Services & 3,424 & 0.197 & 2,084 & 0.102 & 1,340 & 0.345 & $16.67 * * *$ \\
\hline Average 2 year growth & 2,900 & 1.110 & 1,745 & 1.100 & 1,155 & 1.125 & $3.258 * * *$ \\
\hline 2 Year compounded growth rate & 3,422 & 0.084 & 2,084 & 0.063 & 1,338 & 0.116 & $4.307 * * *$ \\
\hline Investments & 3,363 & 0.257 & 2,026 & 0.263 & 1,337 & 0.248 & -0.248 \\
\hline Investments (including depreciation) & 3,369 & 0.217 & 2,030 & 0.236 & 1,339 & 0.188 & -1.247 \\
\hline Blockholder present & 1,049 & 0.770 & & & & & \\
\hline Blockholder present (>50\%) & 1,049 & 0.436 & & & & & \\
\hline Financial institution & 1,049 & 0.148 & & & & & \\
\hline Pension funds & 1,049 & 0.003 & & & & & \\
\hline Insurance companies & 1,049 & 0.025 & & & & & \\
\hline Industrials & 1,049 & 0.055 & & & & & \\
\hline Private individuals & 1,049 & 0.106 & & & & & \\
\hline
\end{tabular}

Note: $\mathrm{N}$ is the number of observations. The $t$-test is on the difference between the means in the 19611985 and the 1986-2005 periods. Significance levels are denoted with *** for $1 \%$ and $* *$ for $5 \%$. All variables are defined in the text. 
Table 3: Descriptive statistics for targets and non-targets

\begin{tabular}{|c|c|c|c|c|c|c|c|c|c|c|c|c|c|c|c|}
\hline & \multicolumn{5}{|c|}{ Full sample } & \multicolumn{5}{|c|}{ 1961-1985 } & \multicolumn{5}{|c|}{$1986-2008$} \\
\hline & \multicolumn{2}{|c|}{ Non-targets } & \multicolumn{2}{|c|}{ Targets } & \multirow{2}{*}{$\begin{array}{c}\text { Difference } \\
\text { T-statistic }\end{array}$} & \multicolumn{2}{|c|}{ Non-targets } & \multicolumn{2}{|c|}{ Targets } & \multirow{2}{*}{$\begin{array}{c}\text { Difference } \\
\text { T-statistic }\end{array}$} & \multicolumn{2}{|c|}{ Non-targets } & \multicolumn{2}{|c|}{ Targets } & \multirow{2}{*}{$\begin{array}{c}\text { Difference } \\
\text { T-statistic }\end{array}$} \\
\hline & $\mathrm{N}$ & mean & $\mathrm{N}$ & mean & & $\mathrm{N}$ & mean & $\mathrm{N}$ & mean & & $\mathrm{N}$ & mean & $\mathrm{N}$ & mean & \\
\hline Firm size (mln, 2008 guilders) & 3,224 & 1,360 & 200 & 646 & $-5.561 * * *$ & 1,971 & 381 & 113 & 331 & -0.91 & 1,253 & 2,901 & 87 & 1,056 & $-6.397 * * *$ \\
\hline Tangibility & 3,224 & 0.320 & 200 & 0.290 & $-2.046 * *$ & 1,971 & 0.323 & 113 & 0.272 & $-2.442 * *$ & 1,253 & 0.316 & 87 & 0.313 & -0.164 \\
\hline Depreciation & 3,224 & 0.043 & 200 & 0.046 & 1.057 & 1,971 & 0.041 & 113 & 0.039 & -0.674 & 1,253 & 0.047 & 87 & 0.055 & $1.767 *$ \\
\hline Profitability & 3,224 & 0.097 & 200 & 0.097 & -0.007 & 1,971 & 0.110 & 113 & 0.100 & -1.301 & 1,253 & 0.077 & 87 & 0.094 & 1.621 \\
\hline Market-to-book & 3,224 & 2.115 & 200 & 2.706 & $3.548 * * *$ & 1,971 & 1.915 & 113 & 2.400 & $2.863 * * *$ & 1,253 & 2.431 & 87 & 3.104 & $2.172 * *$ \\
\hline Leverage & 3,224 & 0.487 & 200 & 0.456 & $-2.081 * *$ & 1,971 & 0.465 & 113 & 0.393 & $-3.425 * * *$ & 1,253 & 0.522 & 87 & 0.538 & 0.91 \\
\hline Cash & 3,224 & 0.046 & 200 & 0.060 & $2.067 * *$ & 1,971 & 0.022 & 113 & 0.041 & $2.859 * * *$ & 1,253 & 0.084 & 87 & 0.085 & 0.114 \\
\hline Hot M\&A Market & 3,224 & 0.369 & 200 & 0.700 & $9.844 * * *$ & 1,971 & 0.432 & 113 & 0.832 & $10.782 * * *$ & 1,253 & 0.271 & 87 & 0.529 & $4.671 * * *$ \\
\hline Number of takeover defenses & 3,224 & 1.090 & 200 & 0.885 & $-3.469 * * *$ & 1,971 & 0.844 & 113 & 0.726 & -1.526 & 1,253 & 1.477 & 87 & 1.092 & $-4.485 * * *$ \\
\hline Preference shares & 3,224 & 0.392 & 200 & 0.290 & $-3.074 * * *$ & 1,971 & 0.198 & 113 & 0.097 & $-3.434 * * *$ & 1,253 & 0.698 & 87 & 0.540 & $-2.845 * * *$ \\
\hline Certificates & 3,224 & 0.279 & 200 & 0.285 & 0.196 & 1,971 & 0.215 & 113 & 0.274 & 1.371 & 1,253 & 0.378 & 87 & 0.299 & -1.55 \\
\hline Priority shares & 3,224 & 0.419 & 200 & 0.310 & $-3.224 * * *$ & 1,971 & 0.431 & 113 & 0.354 & -1.649 & 1,253 & 0.401 & 87 & 0.253 & $-3.039 * * *$ \\
\hline Light industrials & 3,224 & 0.219 & 200 & 0.160 & $-2.185^{* *}$ & 1,971 & 0.280 & 113 & 0.212 & $-1.681 *$ & 1,253 & 0.124 & 87 & 0.092 & -0.976 \\
\hline Heavy industrials & 3,224 & 0.395 & 200 & 0.370 & -0.695 & 1,971 & 0.392 & 113 & 0.363 & -0.628 & 1,253 & 0.398 & 87 & 0.379 & -0.349 \\
\hline Retail & 3,224 & 0.123 & 200 & 0.145 & 0.853 & 1,971 & 0.144 & 113 & 0.177 & 0.891 & 1,253 & 0.090 & 87 & 0.103 & 0.392 \\
\hline Transportation & 3,224 & 0.068 & 200 & 0.100 & 1.462 & 1,971 & 0.082 & 113 & 0.159 & $2.209 * *$ & 1,253 & 0.047 & 87 & 0.023 & -1.398 \\
\hline Services & 3,224 & 0.195 & 200 & 0.225 & 0.983 & 1,971 & 0.102 & 113 & 0.088 & -0.505 & 1,253 & 0.341 & 87 & 0.402 & 1.127 \\
\hline Average 2 year growth & 2,811 & 1.110 & 89 & 1.122 & 0.769 & 1,701 & 1.099 & 44 & 1.131 & 1.409 & 1,110 & 1.126 & 45 & 1.114 & -0.481 \\
\hline 2 Year compounded growth rate & 3,222 & 0.085 & 200 & 0.064 & -0.481 & 1,971 & 0.064 & 113 & 0.035 & -0.423 & 1,251 & 0.117 & 87 & 0.100 & -0.34 \\
\hline Investments & 3,170 & 0.248 & 193 & 0.403 & 0.641 & 1,920 & 0.265 & 106 & 0.222 & -0.171 & 1,250 & 0.222 & 87 & 0.624 & 0.913 \\
\hline Investments (including depreciation) & 3,176 & 0.216 & 193 & 0.232 & 0.113 & 1,924 & 0.237 & 106 & 0.213 & -0.103 & 1,252 & 0.183 & 87 & 0.255 & 0.806 \\
\hline Blockholder present & 976 & 0.770 & 73 & 0.767 & -0.065 & & & & & & & & & & \\
\hline Blockholder present $(>50 \%)$ & 976 & 0.438 & 73 & 0.411 & -0.441 & & & & & & & & & & \\
\hline Financial institution & 976 & 0.146 & 73 & 0.170 & 0.923 & & & & & & & & & & \\
\hline Pension funds & 976 & 0.003 & 73 & 0.001 & $-2.971 * * *$ & & & & & & & & & & \\
\hline Insurance companies & 976 & 0.025 & 73 & 0.020 & -1.334 & & & & & & & & & & \\
\hline Industrials & 976 & 0.052 & 73 & 0.086 & 1.567 & & & & & & & & & & \\
\hline Private individuals & 976 & 0.107 & 73 & 0.097 & -0.468 & & & & & & & & & & \\
\hline
\end{tabular}


Table 3 (cont.)

Note: $\mathrm{N}$ is the number of observations. The $t$-test is on the difference between the means of targets and non-targets. Significance levels are denoted with $* * *$ for $1 \%, * *$ for $5 \%$, and $*$ for $1 \%$. All variables are defined in the text. 
Table 4: Logit model for full period

\begin{tabular}{|c|c|c|c|c|c|c|c|c|}
\hline Variables & $\begin{array}{c}(1) \\
\text { Assets }\end{array}$ & $\begin{array}{c}(2) \\
\text { Performance }\end{array}$ & $\begin{array}{c}(3) \\
\text { Financing }\end{array}$ & $\begin{array}{c}(4) \\
\text { Hot M\&A } \\
\text { Market }\end{array}$ & $\begin{array}{c}\text { (5) } \\
\text { Takeover } \\
\text { defenses (a) }\end{array}$ & $\begin{array}{c}(6) \\
\text { Takeover } \\
\text { defenses (b) }\end{array}$ & $\begin{array}{c}\text { (7) } \\
\text { Baseline } \\
\text { (a) }\end{array}$ & $\begin{array}{c}(8) \\
\text { Baseline } \\
\text { (b) }\end{array}$ \\
\hline Firm size (mln, 2008 guilders) & $\begin{array}{c}-0.002 \\
(-0.739)\end{array}$ & & & & & & $\begin{array}{c}0.001 \\
(0.684)\end{array}$ & $\begin{array}{c}0.000 \\
(0.264)\end{array}$ \\
\hline Tangibility & $\begin{array}{c}-0.064 * * \\
(-2.298)\end{array}$ & & & & & & $\begin{array}{c}-0.019 \\
(-1.584)\end{array}$ & $\begin{array}{c}-0.025 \\
(-1.594)\end{array}$ \\
\hline Depreciation & $\begin{array}{c}0.283 * * \\
(2.057)\end{array}$ & & & & & & $\begin{array}{c}0.152^{* *} \\
(2.357)\end{array}$ & $\begin{array}{c}0.200^{* *} \\
(2.309)\end{array}$ \\
\hline Profitability & & $\begin{array}{c}-0.048 \\
(-1.195)\end{array}$ & & & & & $\begin{array}{l}-0.042^{*} \\
(-1.951)\end{array}$ & $\begin{array}{l}-0.052 * \\
(-1.862)\end{array}$ \\
\hline Market-to-book & & $\begin{array}{c}0.020 * * * \\
(3.853)\end{array}$ & & & & & $\begin{array}{c}0.002 \\
(0.716)\end{array}$ & $\begin{array}{c}0.003 \\
(0.820)\end{array}$ \\
\hline Leverage & & & $\begin{array}{l}-0.043 * \\
(-1.744)\end{array}$ & & & & $\begin{array}{c}-0.018 \\
(-1.490)\end{array}$ & $\begin{array}{c}-0.023 \\
(-1.514)\end{array}$ \\
\hline Cash & & & $\begin{array}{c}0.082 * * \\
(1.975)\end{array}$ & & & & $\begin{array}{c}0.046^{* *} \\
(2.548)\end{array}$ & $\begin{array}{c}0.060 * * \\
(2.538)\end{array}$ \\
\hline Hot M\&A Market & & & & $\begin{array}{c}0.046 * * * \\
(6.376)\end{array}$ & & & $\begin{array}{c}0.034 * * * \\
(4.878)\end{array}$ & $\begin{array}{c}0.043 * * * \\
(4.616)\end{array}$ \\
\hline Number of takeover defenses & & & & & $\begin{array}{c}-0.032 * * * \\
(-2.980)\end{array}$ & & $\begin{array}{l}-0.009^{*} \\
(-1.917)\end{array}$ & \\
\hline Preference shares & & & & & & $\begin{array}{c}-0.041 * * \\
(-2.234)\end{array}$ & & $\begin{array}{c}-0.007 \\
(-0.936)\end{array}$ \\
\hline Certificates & & & & & & $\begin{array}{c}0.006 \\
(0.425)\end{array}$ & & $\begin{array}{c}0.003 \\
(0.453)\end{array}$ \\
\hline Priority shares & & & & & & $\begin{array}{c}-0.037 * * \\
(-2.174)\end{array}$ & & $\begin{array}{c}-0.014 * * \\
(-2.052)\end{array}$ \\
\hline
\end{tabular}


Table 4: Logit model for full period (cont.)

\begin{tabular}{|c|c|c|c|c|c|c|c|c|}
\hline Observations & 3,424 & 3,424 & 3,424 & 3,424 & 3,424 & 3,424 & 3,424 & 3,424 \\
\hline No. of targets & 200 & 200 & 200 & 200 & 200 & 200 & 200 & 200 \\
\hline Industry FE & YES & YES & YES & YES & YES & YES & YES & YES \\
\hline Pseudo R-squared & $1.13 \%$ & $1.53 \%$ & $1.01 \%$ & $6.10 \%$ & $1.20 \%$ & $1.64 \%$ & $7.62 \%$ & $7.92 \%$ \\
\hline $\mathrm{ROC}$ & $60 \%$ & $60 \%$ & $57 \%$ & $70 \%$ & $59 \%$ & $60 \%$ & $72 \%$ & $72 \%$ \\
\hline
\end{tabular}

Note: The $z$-values are in parentheses. Significance levels are denoted with $* * *$ for $1 \%$, ** for $5 \%$, and $*$ for $1 \%$. All variables are defined in the text. 
Table 5: Logit model for sub periods

\begin{tabular}{|c|c|c|c|c|c|c|}
\hline Variables & $\begin{array}{c}(1) \\
\text { Baseline }\end{array}$ & $\begin{array}{c}(2) \\
\text { Baseline }\end{array}$ & $\begin{array}{c}\text { (3a) } \\
1961-1985 \\
\end{array}$ & $\begin{array}{c}(4 a) \\
1986-2008 \\
\end{array}$ & $\begin{array}{c}(3 b) \\
1961-1985 \\
\end{array}$ & $\begin{array}{c}(4 b) \\
1986-2008 \\
\end{array}$ \\
\hline Post 1985 (dummy) & & $\begin{array}{c}0.010 * * * \\
(2.655)\end{array}$ & & & & \\
\hline Firm size (mln, 2008 guilders) & $\begin{array}{c}0.001 \\
(0.684)\end{array}$ & $\begin{array}{c}-0.000 \\
(-0.012)\end{array}$ & $\begin{array}{c}0.002 \\
(1.043)\end{array}$ & $\begin{array}{c}-0.007 \\
(-1.605)\end{array}$ & $\begin{array}{c}0.001 \\
(0.684)\end{array}$ & $\begin{array}{c}-0.007 \\
(-1.577)\end{array}$ \\
\hline Tangibility & $\begin{array}{c}-0.019 \\
(-1.584)\end{array}$ & $\begin{array}{c}-0.013 \\
(-1.439)\end{array}$ & $\begin{array}{c}-0.027 \\
(-1.576)\end{array}$ & $\begin{array}{c}0.021 \\
(0.527)\end{array}$ & $\begin{array}{c}-0.031 \\
(-1.551)\end{array}$ & $\begin{array}{c}0.025 \\
(0.557)\end{array}$ \\
\hline Depreciation & $\begin{array}{c}0.152^{* *} \\
(2.357)\end{array}$ & $\begin{array}{l}0.096 * \\
(1.925)\end{array}$ & $\begin{array}{c}0.107 \\
(1.313)\end{array}$ & $\begin{array}{c}0.154 \\
(0.932)\end{array}$ & $\begin{array}{c}0.127 \\
(1.315)\end{array}$ & $\begin{array}{c}0.174 \\
(0.908)\end{array}$ \\
\hline Profitability & $\begin{array}{l}-0.042^{*} \\
(-1.951)\end{array}$ & $\begin{array}{c}-0.026 \\
(-1.613)\end{array}$ & $\begin{array}{c}-0.046 \\
(-1.423)\end{array}$ & $\begin{array}{c}0.073 \\
(1.052)\end{array}$ & $\begin{array}{c}-0.053 \\
(-1.420)\end{array}$ & $\begin{array}{c}0.076 \\
(1.004)\end{array}$ \\
\hline Market-to-book & $\begin{array}{c}0.002 \\
(0.716)\end{array}$ & $\begin{array}{c}0.001 \\
(0.669)\end{array}$ & $\begin{array}{c}0.000 \\
(0.027)\end{array}$ & $\begin{array}{c}0.001 \\
(0.083)\end{array}$ & $\begin{array}{c}-0.000 \\
(-0.016)\end{array}$ & $\begin{array}{c}0.002 \\
(0.238)\end{array}$ \\
\hline Leverage & $\begin{array}{c}-0.018 \\
(-1.490)\end{array}$ & $\begin{array}{l}-0.015^{*} \\
(-1.690)\end{array}$ & $\begin{array}{l}-0.021^{*} \\
(-1.703)\end{array}$ & $\begin{array}{c}0.016 \\
(0.366)\end{array}$ & $\begin{array}{l}-0.023^{*} \\
(-1.707)\end{array}$ & $\begin{array}{c}0.017 \\
(0.358)\end{array}$ \\
\hline Cash & $\begin{array}{c}0.046^{* *} \\
(2.548)\end{array}$ & $\begin{array}{c}0.021 \\
(1.296)\end{array}$ & $\begin{array}{c}0.073^{* *} \\
(2.340)\end{array}$ & $\begin{array}{c}-0.044 \\
(-0.620)\end{array}$ & $\begin{array}{c}0.084^{* *} \\
(2.281)\end{array}$ & $\begin{array}{c}-0.044 \\
(-0.567)\end{array}$ \\
\hline Hot M\&A Market & $\begin{array}{c}0.034 * * * \\
(4.878)\end{array}$ & $\begin{array}{c}0.025 * * * \\
(4.007)\end{array}$ & $\begin{array}{c}0.030 * * * \\
(2.759)\end{array}$ & $\begin{array}{c}0.048 * * * \\
(3.346)\end{array}$ & $\begin{array}{c}0.034 * * * \\
(2.704)\end{array}$ & $\begin{array}{c}0.052 * * * \\
(2.807)\end{array}$ \\
\hline Number of takeover defenses & $\begin{array}{l}-0.009^{*} \\
(-1.917) \\
\end{array}$ & $\begin{array}{c}-0.009 * * \\
(-2.425) \\
\end{array}$ & $\begin{array}{c}-0.004 \\
(-1.038) \\
\end{array}$ & $\begin{array}{c}-0.052 * * \\
(-2.537) \\
\end{array}$ & & \\
\hline Preference shares & & & & & $\begin{array}{c}-0.005 \\
(-0.603)\end{array}$ & $\begin{array}{c}-0.031 * * \\
(-2.204)\end{array}$ \\
\hline Certificates & & & & & $\begin{array}{c}0.002 \\
(0.405)\end{array}$ & $\begin{array}{c}-0.024 \\
(-1.332)\end{array}$ \\
\hline Priority shares & & & & & $\begin{array}{c}-0.003 \\
(-0.779) \\
\end{array}$ & $\begin{array}{l}-0.039^{*} \\
(-1.936) \\
\end{array}$ \\
\hline Observations & 3,424 & 3,424 & 2,084 & 1,340 & 2,084 & 1,340 \\
\hline No. of targets & 200 & 200 & 113 & 87 & 113 & 87 \\
\hline Industry FE & YES & YES & YES & YES & YES & YES \\
\hline Pseudo R-squared & $7.62 \%$ & $8.08 \%$ & $12.80 \%$ & $8.12 \%$ & $13 \%$ & $9 \%$ \\
\hline ROC & $72 \%$ & $73 \%$ & $78 \%$ & $73 \%$ & $78 \%$ & $73 \%$ \\
\hline \multicolumn{7}{|c|}{ Variance decomposition } \\
\hline Assets & $7 \%$ & $6 \%$ & $8 \%$ & $17 \%$ & $7 \%$ & $16 \%$ \\
\hline Performance & $8 \%$ & $7 \%$ & $8 \%$ & $7 \%$ & $8 \%$ & $6 \%$ \\
\hline Financing & $8 \%$ & $7 \%$ & $18 \%$ & $2 \%$ & $18 \%$ & $2 \%$ \\
\hline Hot M\&A Market & $65 \%$ & $61 \%$ & $56 \%$ & $41 \%$ & $54 \%$ & $38 \%$ \\
\hline Takeover defenses & $6 \%$ & $6 \%$ & $2 \%$ & $29 \%$ & $6 \%$ & $34 \%$ \\
\hline Industry FE & $7 \%$ & $6 \%$ & $8 \%$ & $4 \%$ & $7 \%$ & $5 \%$ \\
\hline
\end{tabular}

Note: The $z$-values are in parentheses. Significance levels are denoted with $* * *$ for $1 \%$, ** for $5 \%$, and $*$ for $1 \%$. All variables are defined in the text. 
Table 6: Logit model with ownership data

\begin{tabular}{|c|c|c|c|c|c|c|c|c|c|}
\hline & $(1)$ & $(2)$ & (3) & $(4)$ & $(5)$ & $(6)$ & $(7)$ & $(8)$ & $(9)$ \\
\hline Firm size (mln, 2008 guilders) & $\begin{array}{c}-0.007 \\
(-1.611)\end{array}$ & $\begin{array}{c}-0.007 \\
(-1.635)\end{array}$ & $\begin{array}{c}-0.007 \\
(-1.531)\end{array}$ & $\begin{array}{c}-0.006 \\
(-1.314)\end{array}$ & $\begin{array}{c}-0.007 \\
(-1.492)\end{array}$ & $\begin{array}{c}-0.007 \\
(-1.526)\end{array}$ & $\begin{array}{l}-0.008^{*} \\
(-1.764)\end{array}$ & $\begin{array}{c}-0.008 * \\
(-1.679)\end{array}$ & $\begin{array}{c}-0.006 \\
(-1.321)\end{array}$ \\
\hline Tangibility & $\begin{array}{c}0.009 \\
(0.207)\end{array}$ & $\begin{array}{c}0.010 \\
(0.236)\end{array}$ & $\begin{array}{c}0.011 \\
(0.221)\end{array}$ & $\begin{array}{c}0.001 \\
(0.027)\end{array}$ & $\begin{array}{c}0.009 \\
(0.182)\end{array}$ & $\begin{array}{c}0.011 \\
(0.220)\end{array}$ & $\begin{array}{c}0.013 \\
(0.282)\end{array}$ & $\begin{array}{c}0.008 \\
(0.155)\end{array}$ & $\begin{array}{c}-0.000 \\
(-0.009)\end{array}$ \\
\hline Depreciation & $\begin{array}{c}0.182 \\
(1.103)\end{array}$ & $\begin{array}{c}0.185 \\
(1.164)\end{array}$ & $\begin{array}{c}0.198 \\
(1.111)\end{array}$ & $\begin{array}{c}0.205 \\
(1.137)\end{array}$ & $\begin{array}{c}0.191 \\
(1.059)\end{array}$ & $\begin{array}{c}0.199 \\
(1.112)\end{array}$ & $\begin{array}{c}0.171 \\
(0.987)\end{array}$ & $\begin{array}{c}0.204 \\
(1.114)\end{array}$ & $\begin{array}{c}0.167 \\
(0.974)\end{array}$ \\
\hline Profitability & $\begin{array}{c}0.060 \\
(0.894)\end{array}$ & $\begin{array}{c}0.059 \\
(0.913)\end{array}$ & $\begin{array}{c}0.070 \\
(0.923)\end{array}$ & $\begin{array}{c}0.065 \\
(0.877)\end{array}$ & $\begin{array}{c}0.071 \\
(0.930)\end{array}$ & $\begin{array}{c}0.070 \\
(0.926)\end{array}$ & $\begin{array}{c}0.078 \\
(1.056)\end{array}$ & $\begin{array}{c}0.071 \\
(0.926)\end{array}$ & $\begin{array}{c}0.068 \\
(0.965)\end{array}$ \\
\hline Market-to-book & $\begin{array}{c}0.010 \\
(1.088)\end{array}$ & $\begin{array}{c}0.009 \\
(1.124)\end{array}$ & $\begin{array}{c}0.011 \\
(1.108)\end{array}$ & $\begin{array}{c}0.012 \\
(1.288)\end{array}$ & $\begin{array}{c}0.012 \\
(1.190)\end{array}$ & $\begin{array}{c}0.011 \\
(1.094)\end{array}$ & $\begin{array}{c}0.010 \\
(1.076)\end{array}$ & $\begin{array}{c}0.014 \\
(1.366)\end{array}$ & $\begin{array}{c}0.013 \\
(1.309)\end{array}$ \\
\hline Leverage & $\begin{array}{c}0.004 \\
(0.083)\end{array}$ & $\begin{array}{c}0.004 \\
(0.095)\end{array}$ & $\begin{array}{c}0.005 \\
(0.095)\end{array}$ & $\begin{array}{c}-0.010 \\
(-0.198)\end{array}$ & $\begin{array}{c}0.013 \\
(0.257)\end{array}$ & $\begin{array}{c}0.005 \\
(0.097)\end{array}$ & $\begin{array}{c}0.007 \\
(0.151)\end{array}$ & $\begin{array}{c}-0.004 \\
(-0.075)\end{array}$ & $\begin{array}{c}-0.009 \\
(-0.196)\end{array}$ \\
\hline Cash & $\begin{array}{c}-0.060 \\
(-0.793)\end{array}$ & $\begin{array}{c}-0.057 \\
(-0.775)\end{array}$ & $\begin{array}{c}-0.064 \\
(-0.784)\end{array}$ & $\begin{array}{c}-0.072 \\
(-0.869)\end{array}$ & $\begin{array}{c}-0.069 \\
(-0.840)\end{array}$ & $\begin{array}{c}-0.065 \\
(-0.783)\end{array}$ & $\begin{array}{c}-0.069 \\
(-0.838)\end{array}$ & $\begin{array}{c}-0.064 \\
(-0.775)\end{array}$ & $\begin{array}{c}-0.089 \\
(-1.056)\end{array}$ \\
\hline Hot M\&A Market & $\begin{array}{c}0.040 * * * \\
(2.937)\end{array}$ & $\begin{array}{c}0.038 * * * \\
(2.904)\end{array}$ & $\begin{array}{c}0.042 * * * \\
(2.772)\end{array}$ & $\begin{array}{c}0.041 * * * \\
(2.756)\end{array}$ & $\begin{array}{c}0.041 * * * \\
(2.717)\end{array}$ & $\begin{array}{c}0.042 * * * \\
(2.709)\end{array}$ & $\begin{array}{c}0.040 * * * \\
(2.734)\end{array}$ & $\begin{array}{c}0.043 * * * \\
(2.753)\end{array}$ & $\begin{array}{c}0.037 * * * \\
(2.673)\end{array}$ \\
\hline Number of takeover defenses & $\begin{array}{c}-0.045^{* *} \\
(-2.370) \\
\end{array}$ & $\begin{array}{c}-0.042 * * \\
(-2.276) \\
\end{array}$ & $\begin{array}{c}-0.047 * * \\
(-2.182) \\
\end{array}$ & $\begin{array}{c}-0.050 * * \\
(-2.181)\end{array}$ & $\begin{array}{c}-0.047 * * \\
(-2.224) \\
\end{array}$ & $\begin{array}{c}-0.047 * * \\
(-2.110)\end{array}$ & $\begin{array}{c}-0.043 * * \\
(-2.144) \\
\end{array}$ & $\begin{array}{c}-0.050 * * \\
(-2.290) \\
\end{array}$ & $\begin{array}{c}-0.046 * * \\
(-2.217)\end{array}$ \\
\hline Blockholder present & & $\begin{array}{c}-0.009 \\
(-0.700)\end{array}$ & & & & & & & \\
\hline Blockholder present $(>50 \%)$ & & & $\begin{array}{c}-0.008 \\
(-0.545)\end{array}$ & $\begin{array}{c}-0.016 \\
(-0.862)\end{array}$ & $\begin{array}{c}-0.007 \\
(-0.486)\end{array}$ & $\begin{array}{c}-0.008 \\
(-0.532)\end{array}$ & $\begin{array}{c}-0.020 \\
(-1.102)\end{array}$ & $\begin{array}{c}-0.001 \\
(-0.050)\end{array}$ & $\begin{array}{c}-0.041 \\
(-1.476)\end{array}$ \\
\hline Financial institution & & & & $\begin{array}{c}0.058 \\
(1.035)\end{array}$ & & & & & $\begin{array}{l}0.108 * \\
(1.650)\end{array}$ \\
\hline Pension funds & & & & & $\begin{array}{c}-1.320 \\
(-1.452)\end{array}$ & & & & $\begin{array}{c}-0.988 \\
(-1.165)\end{array}$ \\
\hline Insurance companies & & & & & & $\begin{array}{c}-0.016 \\
(-0.096)\end{array}$ & & & \\
\hline Industrials & & & & & & & $\begin{array}{c}0.107 * * \\
(1.975)\end{array}$ & & $\begin{array}{c}0.154 * * \\
(2.091)\end{array}$ \\
\hline Private individuals & & & & & & & & $\begin{array}{c}-0.068 \\
(-1.174)\end{array}$ & $\begin{array}{c}0.021 \\
(0.339)\end{array}$ \\
\hline
\end{tabular}


Table 6 (cont.)

\begin{tabular}{|c|c|c|c|c|c|c|c|c|c|}
\hline Observations & 1,062 & 1,049 & 1,049 & 1,049 & 1,049 & 1,049 & 1,049 & 1,049 & 1,049 \\
\hline No. of targets & 73 & 73 & 73 & 73 & 73 & 73 & 73 & 73 & 73 \\
\hline Industry FE & YES & YES & YES & YES & YES & YES & YES & YES & YES \\
\hline Pseudo R & $8 \%$ & $8 \%$ & $8 \%$ & $8 \%$ & $8 \%$ & $8 \%$ & $8 \%$ & $8 \%$ & $10 \%$ \\
\hline $\mathrm{ROC}$ & $72 \%$ & $71 \%$ & $72 \%$ & $72 \%$ & $73 \%$ & $72 \%$ & $73 \%$ & $72 \%$ & $74 \%$ \\
\hline \multicolumn{10}{|c|}{ Variance decomposition } \\
\hline Assets & $19 \%$ & $19 \%$ & $19 \%$ & $17 \%$ & $17 \%$ & $19 \%$ & $18 \%$ & $19 \%$ & $12 \%$ \\
\hline Performance & $15 \%$ & $15 \%$ & $15 \%$ & $15 \%$ & $14 \%$ & $15 \%$ & $14 \%$ & $15 \%$ & $12 \%$ \\
\hline Financing & $3 \%$ & $3 \%$ & $3 \%$ & $2 \%$ & $3 \%$ & $3 \%$ & $3 \%$ & $2 \%$ & $3 \%$ \\
\hline Hot M\&A Market & $37 \%$ & $37 \%$ & $37 \%$ & $35 \%$ & $34 \%$ & $36 \%$ & $32 \%$ & $35 \%$ & $27 \%$ \\
\hline Takeover defenses & $25 \%$ & $24 \%$ & $24 \%$ & $24 \%$ & $22 \%$ & $24 \%$ & $20 \%$ & $23 \%$ & $18.87 \%$ \\
\hline Blockholders & & $1 \%$ & $1 \%$ & $5 \%$ & $8 \%$ & $2 \%$ & $11 \%$ & $3 \%$ & $26.10 \%$ \\
\hline Industry FE & $2 \%$ & $2 \%$ & $2 \%$ & $1 \%$ & $2 \%$ & $2 \%$ & $1 \%$ & $2 \%$ & $1 \%$ \\
\hline
\end{tabular}

Note: The $z$-values are in parentheses. Significance levels are denoted with $* * *$ for $1 \%, * *$ for $5 \%$, and $*$ for $10 \%$. All variables are defined in the text. 
Table 7: Robustness analysis

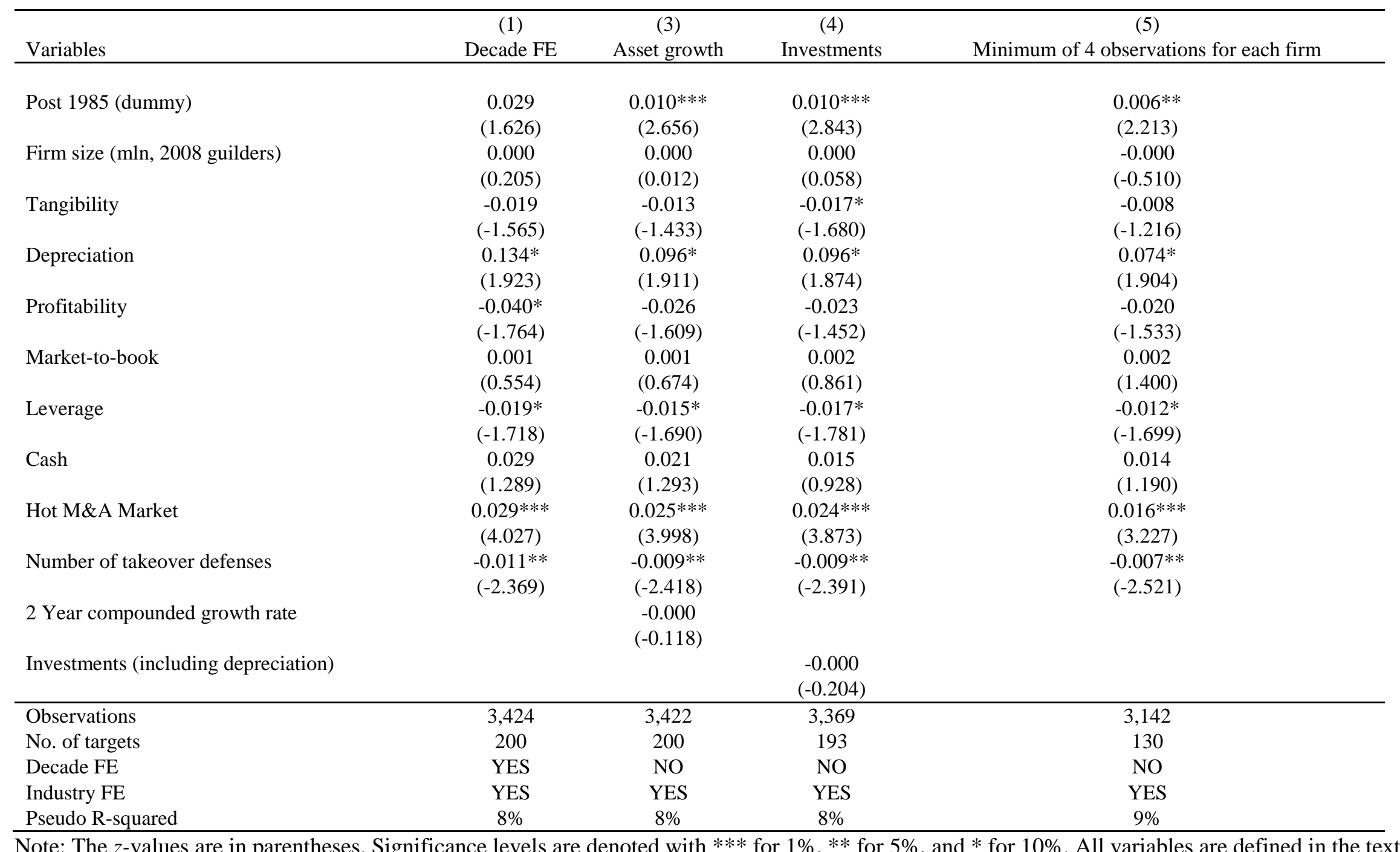

